\title{
Диференційований підхід до вибору способу дислокації тонкокишкового трансплантата в порожнину малого таза
}

\author{
В. М. Мельник, О. І. Пойда, А. А. Кадір
}

Національний медичний університет імені О. О. Богомольця, м. Київ

\section{Differentiated approach to choice of method for the small bowel transplant shifting into the small pelvis cavity}

\author{
V. M. Melnyk, O. I. Poyda, A. A. Qadir \\ Bogomolets National Medical University, Kyiv
}

\section{Реферат}

Мета. Покращити результати реконструктивно-відновних операцій після колектомії з наднизькою передньою резекцією прямої кишки шляхом оптимізації методів забезпечення вільної дислокації тонкокишкового трансплантата в порожнину малого таза.

Матеріали і методи. Розроблені нові способи дислокації тонкокишкового трансплантата під час виконання реконструктивно-відновних операцій після колектомії з наднизькою передньою резекцією прямої кишки, мукозектомії хірургічного анального каналу, які передбачають мобілізацію кореня брижі тонкої кишки, пересічення судинної аркади верхньої брижової артерії (ВБА) та прямих ії судин. Зазначені способи використано у 32 пацієнтів у комплексі 3 відомими методами в складних анатомічних умовах залежно від анатомічних особливостей брижі тонкої кишки, розташування відрізка клубової кишки, архітектоніки ВБА.

Результати. Ускладнень в ранньому післяопераційному періоді, обумовлених дислокацією тонкокишкового трансплантата в порожнину малого таза, у оперованих пацієнтів не спостерігали. В пізньому післяопераційному періоді у 1 (3,1\%) пацієнта виник ішемічний резервуарит, який не був пов'язаний з особливостями техніки дислокації.

Висновки. Розроблені нові способи дислокації тонкокишкового трансплантата після резекції термінальної ділянки клубової кишки сприяють збільшенню його довжини та покращенню мобільності. Диференційований підхід до використання розроблених нових способів дислокації тонкокишкового трансплантата в комплексі 3 відомими методами забезпечував переміщення трансплантата в порожнину малого таза в складних анатомічних умовах, обумовлених зменшенням довжини термінальної ділянки клубової кишки, без натягу брижі тонкої кишки, суттєвого ризику виникнення його ішемії та некрозу.

Ключові слова: реконструктивно-відновні операції; товста кишка; тонкокишковий трансплантат.

\section{Abstract}

Objective. To improve the results of reconstructive-restoration operations after colectomy with a super-low anterior rectal resection due to optimization of the method, which provide a free shifting of a small bowel transplant into a small pelvis cavity. Materials and methods. There were elaborated a new methods of shifting of the small bowel transplant while conduction of reconstructive-restoration operations after colectomy with a super-low anterior rectal resection, mucosectomy of surgical anal channel, which must be accompanied with mobilization of a small bowel mesentery root, transection of vascular arcade of upper mesenterial artery (UMA) and her direct vessels. These procedures were applied in 32 patients in combination with the known methods in complex anatomical peculiarities of the small bowel mesentery, its ileal part localization, and the UMA architectonics. Results. The complications in early postoperative period, caused by the small bowel transplant shifting into the small pelvis cavity in the patients operated were absent. In late postoperative period in $1(3.1 \%)$ patient an ischemic reservoiritis have occurred, which was not caused by the shifting procedure peculiarities.

Conclusion. The elaborated new methods of the small bowel transplant shifting after resection of ileal terminal portion promotes enhancement of its length and improvement of mobility. Differentiated approach for application of a new elaborated methods for shifting of a small bowel transplant in complex of known methods have guaranteed the transplant transposition into the small pelvis cavity in complex anatomic environment, caused by reduction of length of the ileum terminal portion without tension to a small bowel mesentery, as well as the essential risk for its ischemia and necrosis occurrence.

Keywords: reconstructive-restoration operations; large bowel; transplant of small bowel.

Під час формування тазових тонкокишкових резервуарних конструкцій після найбільш обширної органозберігаючої радикальної операції в хірургії товстої кишки колектомії з наднизькою передньою резекцією прямої кишки, мукозектомії хірургічного анального каналу виникає необхідність дислокації тонкокишкового трансплантата в порожнину малого таза, яка у 27,1 - 33,2\% пацієнтів супроводжується технічними труднощами, обумов- леними переважно короткою та масивною брижею тонкої кишки внаслідок ії анатомічних особливостей, ожиріння, а також розсипного типу архітектоніки ВБА $[1,2]$.

Відомі методи дислокації тонкокишкового трансплантата в порожнину малого таза передбачають мобілізацію брижі тонкої кишки в безсудинній ділянці, пересічення верхніх брижових артерії та вени в нижній та середній третинах стовбура з наступним анастомозуванням дис- 
тальних відрізків цих судин відповідно з клубовою артерією та веною [1]. Використання зазначених методів у більшості спостережень не забезпечує досягнення бажаного результату, а окремі з них включають формування міжсудинних анастомозів, що технічно ускладнює виконання реконструктивно-відновних операцій, створює ризик виникнення тромбоемболічних ускладнень, ішемії та некрозу трансплантата. Зазначені фактори обумовили необхідність удосконалення відомих та розробку нових методів дислокації тонкокишкового трансплантата.

Мета дослідження: покращити результати реконструктивно-відновних операцій після колектомії з наднизькою передньою резекцією прямої кишки шляхом оптимізації методів забезпечення вільної дислокації тонкокишкового трансплантата в порожнину малого таза.

\section{Матеріали і методи дослідження}

Для оптимізації методів дислокації тонкокишкового трансплантата в порожнину малого таза використовували відомі, а також розроблені авторські способи, спрямовані на забезпечення мобільності кореня брижі тонкої кишки, достатньої довжини трансплантата, зменшення ризику виникнення його ішемії та некрозу.

Техніка авторського способу дислокації тонкокишкового трансплантата в порожнину малого таза [3] (puc. 1): пересікали перехідний листок очеревини по периметру кореня брижі тонкої кишки, мобілізували корінь брижі до нижнього краю підшлункової залози, на рівні якого ВБА та корінь брижі тонкої кишки розташовуються в ділянці задньої стінки живота і стають доступними для мобілізації.

Авторський спосіб мобілізації тонкокишкового трансплантата, який забезпечує збільшення довжини брижі тонкої кишки [4], використовували після колектомії з наднизькою передньою резекцією прямої кишки, доповненою резекцією термінальної ділянки клубової кишки, видалення якої передбачало пересічення клубово-ободової артерії, ВБА на рівні дистальної третини ії стовбура. Після цього пересікали термінальну артеріальну дугу першого порядку відрізка клубової кишки, а також одну або дві ії прямі артерії (рис. 2). Спосіб уможливлював збільшення довжини тонкокишкового трансплантата до 15 - 20 см та покращення його мобільності.

Дислокацію тонкокишкового трансплантата в порожнину малого таза застосували у 32 пацієнтів під час виконання реконструктивно-відновного етапу хірургічного втручання в період з 2008 по 2017 р. Чоловіків було 18 (56,3\%), жінок - 14 (43,8\%). Вік оперованих пацієнтів становив від 18 до 35 років. 3 приводу тяжких форм виразкового коліту оперували 14 (43,8\%) пацієнтів, хвороби Крона товстої кишки - 8 (25,0\%), родинного аденоматозного поліпозу - 10 (31,3\%). Супутні захворювання (цукровий діабет, ожиріння, варикозна хвороба поверхневих вен нижніх кінцівок, есенціальна тромбоцитопенія) діагностовані у 7 (21,9\%) пацієнтів.

Реконструктивно-відновний етап хірургічного втручання полягав у формуванні тазового тонкокишкового резервуара нового типу [5] та ілеоендоанального анастомоза [6]. Для формування резервуара необхідно було використати не менше 40 - 45 см термінальної ділянки клу-

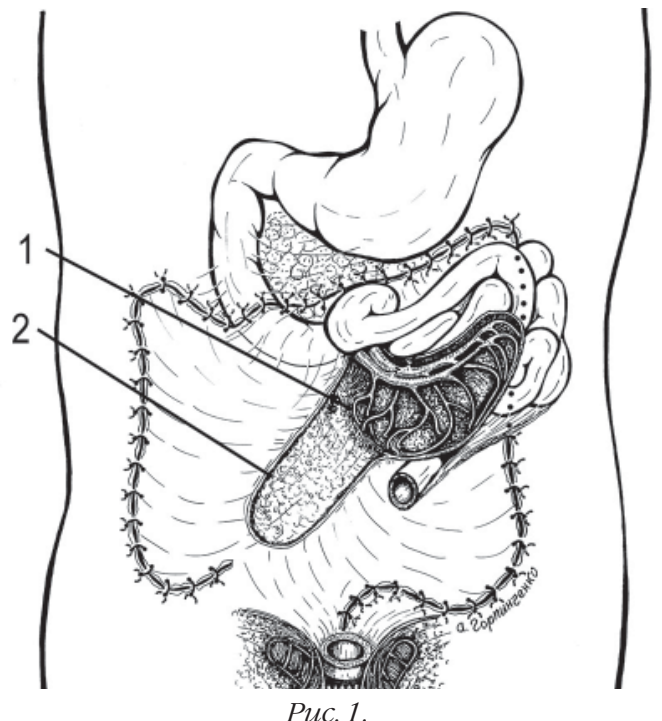

Спосіб дислокацї тонкокиикового трансплантата в порожнину малого таза шляхом пересічення перехідного листка очеревини по периметру кореня брижі тонкої киики: 1 - лінія пересічення перехідного листка очеревини по периметру кореня брижі тонкої кишки; 2 -мобілізований корінь брижі тонкоїкишки.

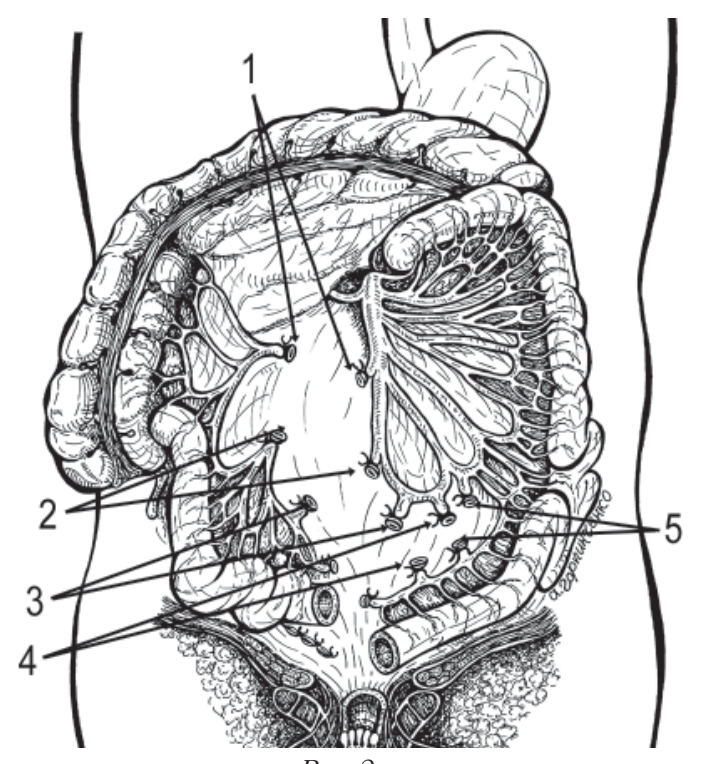

Спосіб мобілізациї тонкокишкового трансплантата иляхом пересічення термінальної артеріальної ууи відрізка клубової киики та ї̈ прямих судин;

етап мобілізацї правої половини товстої кищки

та термінальноӥ ділянки клубової кишки:

1 - ліговані відрізки клубово-ободової артеріі;

2 - ліговані відрізки стовбура ВБА на рівні середнъої та нижнъої його третин; 3 - ліговані відрізки термінальної артеріальної ууги першого порядку;

4,5 - ліговані відрізки прямих артерій термінальноі артеріальноїдуги периого порядку.

бової кишки включно з пострезервуарною ділянкою, що створювало певні труднощі для дислокації тонкокишкового трансплантата.

Первинні реконструктивно-відновні операції виконали 25 (78,1\%) пацієнтам, вторинні - 7 (21,9\%). Під час виконання вторинних реконструктивно-відновних опера- 
цій виникали додаткові технічні труднощі через злуковий процес між петлями тонкої кишки, петлями тонкої кишки та парієтальною очеревиною.

Оперованих пацієнтів умовно розподілили на дві групи залежно від обсягу радикального етапу хірургічного втручання та вибору методів дислокації тонкокишкового трансплантата в порожнину малого таза. До 1-ї групи включили 21 (65,6\%) пацієнта. Радикальний етап хірургічного втручання у пацієнтів цієї групи передбачав виконання колектомії з наднизькою передньою резекцією прямої кишки, мукозектомії хірургічного анального каналу. У них використовували розроблений спосіб дислокації тонкокишкового трансплантата в порожнину малого таза, який передбачає пересічення перехідного листка очеревини по периметру кореня брижі тонкої кишки, мобілізацію кореня брижі до нижнього краю підшлункової залози. У більшості пацієнтів цей спосіб доповнювали пересіченням брижі тонкої кишки в безсудинних ділянках. Зазначений комплекс заходів застосовували за наявності короткої брижі тонкої кишки та розсипного типу архітектоніки ВБА.

У 11 (34,4\%) пацієнтів, включених до 2-ї групи, крім колектомії $з$ наднизькою передньою резекцією прямої кишки, мукозектомії хірургічного анального каналу, виконували резекцію термінальної ділянки клубової кишки протяжністю 15 - 70 см. У 4 паціентів необхідність видалення термінальної ділянки клубової кишки була обумовлена патологічними змінами внаслідок хвороби Крона, у 2 - внаслідок термінального ілеїту при виразковому коліті. У 5 пацієнтів термінальну ділянку клубової кишки видалили для попередження рецидиву патологічного процесу в пізньому післяопераційному періоді за наявного його високого ризику.

Для дислокації тонкокишкового трансплантата у цих пацієнтів, крім пересічення перехідного листка очеревини по периметру кореня брижі тонкої кишки, мобілі-

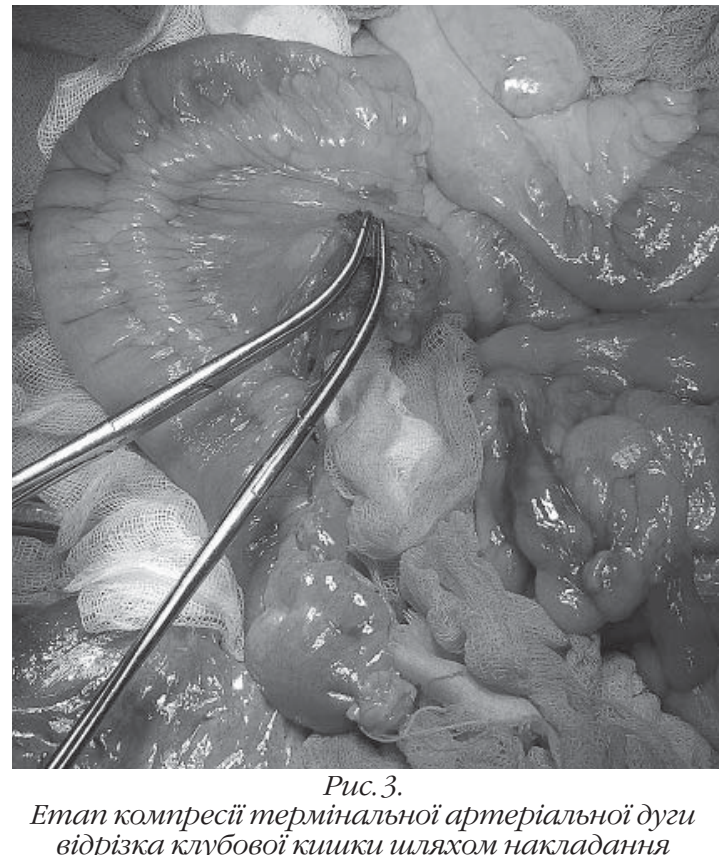

відрізка клубовоїкишки шляхом накладання судинних затискачів. зації кореня брижі до нижнього краю підшлункової залози, пересічення брижі тонкої кишки в безсудинних ділянках, використовували розроблений спосіб мобілізації тонкокишкового трансплантата, відповідно до якого пересікали термінальну артеріальну дугу першого порядку відрізка клубової кишки, а також одну або дві ії прямі артеріі. Вказаний комплекс заходів забезпечував дислокацію тонкокишкового трансплантата у разі додаткового зменшення його довжини внаслідок резекції термінальної ділянки клубової кишки.

Життездатність трансплантата визначали за результатами резервуароскопії, яку виконували не раніше 7-ї доби після операції, коли наставала надійна фіксація відрізків ілеоендоанального анастомоза. В подальшому за наявності показань резервуароскопію та резервуарографію виконували з метою виключення ймовірного ішемічного резервуариту та стриктури пострезервуарної ділянки клубової кишки.

\section{Результати}

Диференційований підхід до вибору комплексу заходів та послідовності їх використання залежно від анатомічних особливостей брижі тонкої кишки, розташування відрізка тонкої кишки, архітектоніки ВБА забезпечував вільну дислокацію тонкокишкового трансплантата в порожнину малого таза без натягу брижі тонкої кишки. Трансплантат вважали життездатним, а його дислокацію в порожнину малого таза можливою за наявності відпрацьованих критеріїв життєздатності: збереження природного блідо-рожевого кольору, тонусу стінки тонкої кишки, перистальтики, кровоточивості в ділянці зрізу. Перед використанням способу дислокації, який передбачав пересічення термінальної артеріальної дуги та прямих її судин, застосовували тимчасову пальцеву компресію або компресію шляхом накладання затискачів на гілки вказаних судин з наступною оцінкою життєздатності тонкокишкового трансплантата в басейні їх кровопостачання (рuс.3). Зазначені судини пересікали лише після позитивної оцінки життєздатності трансплантата на підставі наявності вказаних відпрацьованих критеріїв.

Ускладнень в ранньому післяопераційному періоді, обумовлених дислокацією тонкокишкового трансплантата в порожнину малого таза, у оперованих пацієнтів не спостерігали.

Під час резервуароскопії на 7-му добу після операції термінальна ділянка тонкокишкового трансплантата у всіх пацієнтів була життездатною, ознак гострої ішемії або некрозу трансплантата не встановлено. У 1 (3,1\%) пацієнта, оперованого з приводу родинного аденоматозного поліпозу, ускладненого аденокарциномою прямої кишки, через 14 міс після хірургічного втручання виникла ішемія тонкокишкового резервуара, яка мала прояви ішемічного резервуариту. Терапія резервуариту з призначенням ангіопротекторів, препаратів для покращення реологічних властивостей крові, мікроциркуляції упродовж 8 міс виявилась неефективною. Під час контрольної комп'ютерної томографії органів черевної порожнини констатували імплантаційні метастази в брижу тонкої кишки та парієтальну очеревину порожнини малого таза, які чинили 
компресію стовбура та гілок ВБА і були основною причиною виникнення ішемічного резервуариту. Пацієнту виконали екстирпацію кукси анального каналу, ліквідували резервуар, сформували довічну ілеостому за методом Брука.

За даними контрольної резервуароскопії та резервуарографії у інших хворих під час скринінгового та диспансерного обстеження в період спостереження від 1 до 3 років ознак ішемії трансплантата та стриктури пострезервуарної ділянки клубової кишки не констатували.

\section{Обговорення}

Потреба удосконалення технічних аспектів дислокації тонкокишкового трансплантата в порожнину малого таза виникла переважно завдяки двом факторам: впровадженню авторських тонкокишкових резервуарних конструкцій нового типу (на зразок циклорезервуара), формуючи які необхідно було використовувати не менше 40 - 45 см термінальної ділянки клубової кишки; змінам щодо вибору радикального етапу хірургічного втручання з приводу хвороби Крона, обумовленим видаленням 15 - 70 см термінальної ділянки тонкої кишки у разі ії ураження, а також у разі наявного термінального ілеїту при виразковому коліті. Технічні труднощі під час дислокації тонкокишкового трансплантата у кожного оперованого пацієнта обумовлювали необхідність вибору та послідовного використання відомих, а також розробку нових більш досконалих ії способів.

У переважній більшості спостережень, коли була збережена термінальна ділянка клубової кишки, для дислокації достатньо було пересічення перехідного листка очеревини по периметру кореня брижі тонкої кишки, мобілізації кореня брижі до нижнього краю підшлункової залози, а також пересічення брижі тонкої кишки в безсудинних ділянках. Тобто необхідності в пересіченні судин брижі тонкокишкового трансплантата для збільшення його довжини не було, що сприяло адекватному кровопостачанню.

Додаткові труднощі для забезпечення вільної дислокації тонкокишкового трансплантата створювало видалення термінальної ділянки клубової кишки у пацієнтів 3 хворобою Крона товстої кишки у разі ії ураження, наявного термінального ілеїту при виразковому коліті. Тому у таких пацієнтів необхідним було використання не лише відомих методів дислокації тонкокишкового трансплантата в порожнину малого таза, а й удосконалення окремих іiі технічних аспектів, а також тактичних заходів з урахуванням особливостей архітектоніки ВБА і топографічного розташування відрізка тонкої кишки. Тобто крім мобілізації кореня брижі тонкої кишки, пересічення брижі в безсудинних ділянках, необхідним було використання способу мобілізації тонкокишкового трансплантата шляхом пересічення термінальної артеріальної дуги першого порядку і, за необхідності, одніеї або двох ії прямих артерій без значного порушення кровопостачання тонкокишкового трансплантата, що було можливим лише на рівні дистальної ділянки середньої третини ВБА з більш інтенсивним кровопостачанням порівняно з ії нижньою третиною. Зазначені анатомічні особливості виникали саме після резекції термінальної ділянки клубової кишки та видалення їі брижі разом з гілками артеріального басейну нижньої третини ВБА.

Таким чином, диференційований підхід до вибору комплексу заходів, у тому числі авторських способів, спрямованих на забезпечення дислокації тонкокишкового трансплантата, з урахуванням анатомічних особливостей брижі тонкої кишки, розташування термінального відрізка клубової кишки в черевній порожнині, архітектоніки судин ВБА і особливо судин відрізка клубової кишки після видалення ï термінальної ділянки разом з гілками басейну кровопостачання забезпечував можливість дислокації трансплантата в складних умовах нетипового взаєморозташування відрізка тонкої кишки і відрізка хірургічного анального каналу, а також сприяв значному зменшенню ризику виникнення ішемії та некрозу трансплантата, стриктури пострезервуарного відрізка тонкої кишки.

\section{Висновки}

1. Розроблені нові способи дислокації тонкокишкового трансплантата після резекції термінальної ділянки клубової кишки передбачають збільшення довжини трансплантата та покращення його мобільності.

2. Диференційований підхід до використання нових розроблених способів дислокації тонкокишкового трансплантата в комплексі з відомими методами забезпечував вільне переміщення трансплантата в порожнину малого таза в складних анатомічних умовах, обумовлених зменшенням довжини термінальної ділянки клубової кишки, без натягу брижі тонкої кишки, суттевого ризику виникнення його ішемії та некрозу.

\section{References}

1. Vorobey AV, Grishin IN. Reabilitacija stomrovannyh bolnyh. Minsk: Belorusskaya nauka; 2003. 190 s. [In Russian].

2. Poyda AI, Melnik VM. Vosstanovitelnye i rekonstruktivno-vosstanovitelnye operacii na tolstoj kishke. Kyiv: Izdatelskiy centr «Imidzh Ukriiny»; 2014. 368 s. [In Russian].

3. Melnyk VM, Poyda OI, vynakhidnyky; Natsionalniy medichniyi universitet imeni O. O. Bohomoltsia, patentovlasnyk. Sposib dyslokatsii tonkokyshkovoho transplantata u porozhnynu maloho taza. Patent Ukrainy N 71956. 2012 lip 14. [In Ukrainian].

4. Melnyk VM, Poyda OI, vynakhidnyky; Natsionalniy medichniyi universitet imeni O. O. Bohomoltsia, patentovlasnyk. Sposib mobilizatsii tonkokyshkovoho transplantata. Patent Ukrainy N 128180. 2018 ver 17. [In Ukrainian].

5. Melnyk VM, Poyda OI, Kadir Abdulrakhman Abdul, vynakhidnyky; Natsionalniy medichniyi universitet imeni O. O. Bohomoltsia, patentovlasnyk. Sposib formuvannia tonkokyshkovoho tazovoho rezervuara. Rishennia pro vydachu deklaratsiinoho patentu na korysnu model, Ukraina. u 2018 02861. 2018. lip. [In Ukrainian].

6. Melnyk VM, Poyda OI, vynakhidnyky; Natsionalniy medichniyi universitet imeni O. O. Bohomoltsia, patentovlasnyk. Sposib ileoendoanalnoho anastomozu. Patent Ukrainy N 127364. 2018 lip 14. [In Ukrainian]. 